\title{
Kepemimpinan Guru Pendidikan Agama Kristen
}

\author{
Nasib Tua Lumban Gaol \\ Manajemen Pendidikan Kristen, Istitut Agama Kristen Negeri (IAKN), Tarutung \\ nasib.t.lumbangaol@gmail.com \\ Andrianus Nababan \\ Manajemen Pendidikan Kristen, Istitut Agama Kristen Negeri (IAKN), Tarutung \\ andri.nababan1992@gmail.com
}

\begin{abstract}
Christian religious teacher leadership contributes to improving the learning process quality in school and national education contexts. Ironically, Christian religious teachers are still lacking knowledge in leadership, and not applying adequate leadership in the learning process. Thus, this paper was aimed to describe some characteristics of Christian religious teacher leadership that should be implemented. Based on the result of reviewing, these were found some of Christian religious teacher leadership characteristics: (1) serving students with the heart; (2) acting fair according to the truth of God's word; (3) having optimistic to educate; (4) able to manage time well; (5) loving students; (6) making decision objectively and firmly. In an effort to develop the Christian religious teacher leadership, further research and studies are needed to conduct in order to build the Christian religious teacher leadership concept.
\end{abstract}

Keywords: Christian Leadership, Christian Religious Teacher Leadership, Education, Educational Leadership, Learning Process

\section{Article Info}

\section{PENDAHULUAN}

Guru pendidikan agama Kristen merupakan pendidik (educator) yang tidak dapat diabaikan perannya dalam sistem pendidikan Nasional. Undang Undang Republik Indonesi Nomor 20 Tahun 2003 tentang Sistem Pendidikan Nasional, BAB XI Pasal 39 ayat (2) menyebutkan bahwa pendidik merupakan tenaga profesional yang bertugas merencanakan dan melaksanakan proses pembelajaran menilai hasil pembelajaran, melakukan pembimbingan dan pelatihan.

Guru agama Kristen sebagai pendidik harus melakukan tugasnya dengan baik. Kehadiran guru agama Kristen di sekolah semakin vital karena guru agama Kristen tidak saja bertugas hanya sebagai pengajar pengetahuan Kristen, tetapi harus mampu mengembangkan karakter positif siswa. Sehingga, dengan demikian siswa menjadi pribadi yang memiliki spiritualitas dan karakter yang unggul di sekolah maupun di masyarakat. Selain itu, guru agama Kristen harus mampu menjadi inspirasi dan teladan bagi siswa. Ini bertujuan supaya siswa dapat merefleksikan apa yang diajarkan guru, yaitu nilai-nilai kebenaran yang terdapat dalam Alkitab. Selanjutnya, hasil refleksi yang dilakukan siswa akan memunculkan perubahan 
pengetahuan, sikap dan perilaku siswa dalam kehidupan sosial dan pribadi secara bertahap.

Pada dasarnya, proses dan luaran dari pelaksanaan pendidikan yang dilakukan oleh guru agama Kristen di sekolah seharusnya terjadi begitu natural, tanpa ada paksaan atau intimidasi yang mengakibatkan anak seolah tidak bebas dalam berpikir dan bertindak. Dengan begitu, siswa akan merasakan kebebasan dalam mengembangkan pengetahuannya. Pada kondisi inilah guru agama Kristen harus mampu mengkontekstualisasikan kebenaran Alkitab supaya siswa lebih terbuka dan mau menjadikan kebenaran ini sebagai fondasi dalam berpikir dan bertindak. Proses belajar yang demikian dapat terjadi apabila guru bertindak aktif dalam berinteraksi dengan siswa.

Stornks dan Joldersma dalam Wolterstorff (2014:xv) menggarisbawahi bahwa sasaran pendidikan Kristen adalah kehidupan Kristen dan bukan sekedar pemikiran Kristen, sekolah harus memperhatikan lebih banyak kehidupan dan menelusuri kecenderungan-kecenderungan murid untuk menggunakan pengetahuan dan kemampuan mereka dalam menjalani kehidupan. Oleh karena itu, seorang guru agama Kristen sebenarnya tidak cukup hanya memiliki pengetahuan teologis, tetapi harus juga memahami aspek psikologis siswa supaya mampu mendidik siswa sesuai dengan perkembangan mereka. Guru agama Kristen tidak boleh mengabaikan kehidupan siswa yang dalam kesehariannya berhadapan dengan berbagai aspek di lingkungan sekitarnya. Lingkungan tersebut baik secara langsung mapun tidak langsung dapat memengaruhi perkembangan pengetahuan, sikap dan tindakan siswa.

Kepemimpinan merupakan aspek penting yang harus dimiliki oleh setiap guru, termasuk guru agama Kristen. Ketika seorang guru, misalnya, guru agama Kristen tidak 90 memiliki kepemimpinan di sekolah tentu yang menjadi permasalahan adalah guru tidak dapat mengajar siswa dengan optimal. Guru hanya menyampaikan materi pelajaran-tanpa memberikan pengaruh yang cukup berarti kepada siswa. Akibatnya pencapaian belajar siswa di bawah standar.

Meskipun ada penekanan akan begitu pentingnya bidang kepemimpinan guru ini dimana berbagai studi kepemimpinan guru sudah banyak di lakukan baru-baru ini dalam skala internasional, misalnya Haris (2015), Berg \& Zoellick (2018), dan Warren (2018) namun penelitian kepemimpinan guru di Indonesia masih berada pada tahap awal. Hal ini dibuktikan dari masih sulitnya menemukan publikasi kepemimpinan guru dalam konteks Indonesia. Ketika penulis melakukan pecarian di Google Scholar penulis hanya menemukan kajian dari Hasanah \& Fattah (2010) dan Sari (2017). Dengan kata lain, hasil kajian kepemimpinan guru di Indonesia masih perlu dilakukan lebih lanjut.

Berkaitan dengan hal di atas, maka berbagai kajian dan penelitian tentang kepemimpinan guru agama Kristen sangat penting untuk dilakukan. Studi kepemimpinan guru ini, terkhusus guru agama Kristen, masih langka dilakukan di Indonesia. Kondisi ini mengakibatkan minimnya pemahaman dan praktik kepemimpinan di sekolah. Oleh karena itu, studi ini berupaya mengisi kekurangan studi kepemimpinan guru, terkhusus kepemimpinan guru agama Kristen di Indonesia. Secara khusus, studi ini bertujuan menguraikan karakteristik kepemimpinan guru agama Kristen. Untuk mengarahkan fokus pembahasan dalam studi ini, maka rumusan masalahnya adalah: "Apakah karakteristik kepemimpin guru agama Kristen yang sesuai dengan konteks sekolah?".

Dengan adanya kajian ini, diharapkan kepemimpinan guru semakin berkembang, sehingga berkontribusi pada pengembangan profesionalisme guru dan pencapaian belajar 
siswa. Manfaat lain dari studi ini adalah sebagai referensi bagi guru dalam mempraktikkan dan menjalankan tugasnya sebagai pemimpin dan pendidik. Selain itu, untuk penelitian lanjutan, studi ini boleh berguna sebagai referensi pada pengembangan konsep dan praktik kepemimpinan pendidikan di Indonesia, terkhusus pada impelementasi kepemimpinan guru agama Kristen di lingkungan sekolah.

Studi ini merupakan studi pustaka dimana penulis berupaya memberikan deskripsi tentang kepemimpinan guru pendidikan agama Kristen melalui berbagai referensi (Buku dan Jurnal). Dengan melakukan analisis dari berbagai referensi, penulis mengklasifikasikan berbagai karakteristik kepemimpinan yang harus dimiliki oleh guru agama Kristen.

\section{PEMBAHASAN}

Kepemimpinan pendidikan tidak hanya berfokus pada kepemimpinan kepala sekolah, tetapi harus juga kepemimpinan guru. Karena keberhasilan sekolah tidak hanya ditentukan oleh kepala sekolah, tetapi peran penting lain dimiliki oleh guru juga. Hal ini sejalan dengan pendapat Hook (2006) yang menyatakan bahwa ide dari kepemimpinan [pendidikan] harus diperluas dengan mengikutsertakan guru.

Guru pendidikan agama Kristen adalah tenaga pendidik di sekolah yang sering disebut dengan istilah 'guru agama Kristen' atau guru PAK (Pendidikan Agama Kristen). Guru agama Kristen memiliki peran penting dalam mendidik siswa supaya menjadi pribadi yang memahami dan mengamalkan ajaran keKristenan dalam kehidupan sehari-hari. Peran dan tanggung jawab guru agama Kristen ini menuntut kepemimpinan yang memadai.

Mendefinisikan kepemimpinan agak rumit. Hal ini disebabkan "kepemimpinan adalah sangat kompleks dan memiliki berbagai konsep" (Lumban Gaol, 2017). Oleh karenanya, untuk memahami kepemimpinan harus disesuaikan dengan konteksnya. Namun, pada dasarnya, kepemimpinan itu tidak hanya tentang "posisi"-kepemimpinan lebih pada penekanan bagaimana keberadaan individu boleh memberikan pengaruh pada suatu organisasi, sehingga dengan demikian dapat melakukan perubahan ke arah yang lebih baik.

Kepemimpinan merupakan karakteristik yang melekat pada pribadi pemimpin, .dimana pemimpin adalah pribadi yang memimpin. Winardi (2010:89) menyatakan kepemimpinan adalah cara atau teknik pimpinan untuk mengarahkan dan menyuruh orang lain agar mau mengerjakan apa yang ditugaskan. Kepemimpinan adalah pemberian arah dalam membina atau menggerakkan serta mengawasi pihak bawahan, maka syarat-syarat untuk melaksanakan pekerjaan harus dikomunikasikan kepada para anggota, sehingga mereka dapat dimotivasi untuk melaksanakan pekerjaan sesuai dengan sasaran kelompok yang ditetapkan. Selanjutnya, Mardjin yang dikutip oleh Soetopo dan Soemanto (2008:2) menguraikan bahwa "Kepemimpinan adalah keseluruhan dari tindakan guna mempengaruhi serta menggiatkan orang, dalam usaha bersama untuk mencapai tujuan atau dengan definisi yang lengkap dapat dikatakan bahwa kepemimpinan adalah proses pemberian jalan yang mudah (fasilitas) dari pada pekerjaan orang lain yang terorganisir dalam organisasi formal guna mencapai tujuan yang ditetapkan". Dengan demikian, kepemimpinan adalah keseluruhan dari tindakan dalam mempengaruhi serta menggiatkan orang atau pengikut/anggota, dalam usaha bersama untuk mencapai tujuan yang akan dicapai.

\section{Kepemimpinan Kristen}

Kepemimpinan Kristen ada dalam sejarah rencana keselamatan Allah melalui para pemimpin. Pemimpin tersebut adalah sosok pribadi dalam Alkitab, misalnya, Abraham, Ishak, Yakub, Musa, Harun, Yosua, Petrus, dan para Rasul, yang mengajarkan umat Tuhan. Namun, sosok yang paling menjadi fokus dalam kepemimpinan Kristen adalah Yesus itu 
sendiri. Hine (2014) menegaskan bahwa kepemimpinan Kristen didasarkan pada kehidupan dan pengajaran Yesus dari Nazareth. Oleh karena itu, keteladanan dan pengajaran yang diberikan Yesus harus menjadi fondasi penting dalam implementasi kepemimpinan Kristen.

Menurut Tomatala (2002:39) pada hakekatnya hal inti yang dilakukan pemimpin adalah memberikan pengajaran. Berkaitan dengan hal tersebut, kepemimpinan Kristen adalah suatu proses terencana yang dinamis dalam konteks pelayanan Kristen yang menyangkut faktor waktu, tempat dan situasi khusus yang didalamnya oleh campur tangan Allah. Ia memanggil diri-Nya seorang pemimpin dengan kapasitas penuh untuk memimpin umat-Nya yang mengelompokkan diri dalam suatu Institusi atau organisasi guna mencapai tujuan Allah yang membawa keuntungan bagi pemimpin, bawahan, dan lingkungan hidup bagi serta melalui umat-Nya, untuk kejayaan kerajaan-Nya.

Selanjutanya, hal senada juga dikemukakan oleh Wiryoputro (2011:105) yang menyampaikan, jika di dunia ini ada manusia yang mempunyai kuasa mengelola atau memimpin, maka kuasa yang dimilkinya itu berasal dari Tuhan (Mazmur 62:12). Demikian pula jika di dunia ini ada manusia yang mempunyai kebesaran, kejayaan, dan kemuliaan, maka semua yang dimilikinya itu juga berasal dari Tuhan (1Taw. 29:11-12).

Kita mengetahui bahwa ada banyak pemimpin yang mempunyai kuasa, kehormatan, kemasyuran, dan kekayaan, namun semuanya itu tidak berasal dari Tuhan. Oleh karena itu, kepemimpinan Kristen haruslah berfokus kepada Tuhan dan memberikan pengajaran yang bersumber dari Alkitab - tidak berfokus pada diri sendiri atau objek lainnya.

\section{Kepemimpinan Pendidikan}

Istilah kepemimpinan pendidikan dapat dikontekstualkan dengan kepemimpinan kepala sekolah dan kepemimpin guru. Dalam praktiknya di sekolah, kepala sekolah berperan sebagai pemimpin sekolah dan dalam pembelajaran di kelas guru adalah pemimpin. Hal tersebut sejalan dengan pendapat Wirawan (2013) yang membedakan bahwa di sekolah sebagai pemimpin adalah kepala sekolah, sedangkan di dalam ruangan kelas pemimpin adalah seorang guru. Oleh karena itu, kepemimpinan guru adalah proses yang memengaruhi peserta didik untuk mencapai tujuan pembelajaran. Selain itu, kepemimpinan guru juga dapat berkaitan dengan para pemangku kepentingan (stakeholder) pendidikan untuk menciptakan sinergi dalam upaya mencapai tujuan pendidikan.

Di samping guru sebagai tenaga pendidik, guru juga berperan sebagai pemimpin dalam pembelajaran di kelas melalui mata pembelajaran yang diampunya. Guru harus mampu memengaruhi para siswa agar bersikap dan berperilaku sesuai dengan norma yang berlaku di masyarakat. Selain itu, guru juga harus memengaruhi siswanya agar mempelajari pengetahuan dan keterampilan yang diajarkannya (Wirawan, 2013:554). Dengan kata lain, guru merupakan pemimpin bagi anak didiknya. Kepemimpinan guru harus mampu memberikan inspirasi dan keteladanan bagi seluruh komponen warga yang ada di sekolah, terutama bagi peserta didiknya.

Wirawan (2013) mengemukakan bahwa metode kepemimpinan guru dapat dikarakteristikkan dengan tindakan sebagai berikut: (a) mencintai anak didik. Guru bekerja untuk mengembangkan para muridnya agar dapat mandiri dengan hari depan yang cerah. Karena itu guru harus mencintai para muridnya; (b) memimpin peserta didik. Guru merupakan seorang pemimpin yang memengaruhi anak didiknya untuk menguasai materi yang diajarkan; (c) memiliki energi dan antusias. Di dalam kelas guru harus energik dan antusias saat mengajar siswa; (d) kreatif dan inovatif. Kreatif artinya mampu menciptakan ide baru 
jika mengahadapi permasalahan baik perilaku siswa. Inovatif artinya mapu mengubah ide menjadi barang dan jasa untuk menyelesaikan permasalahan dalam belajar dan siswa; (e) optimis dan idealis. Guru harus seorang yang optmis mampu mengubah para siswanya menjadi manusia yang berkembang ilmu pengetahuan, sikap dan perilaku menjadi orang yang lebih baik setiap hari; (f) memiliki rasa humor, guru memang harus serius dalam mengajar, akan tetapi ia juga harus seorang ynag penuh humor dalam mengajar; (g) mengembangkan iklim kelas. Guru juga harus mengembangkan iklim psikologis, tidak malu, tidak rendah diri jika melakukan kesalahan. Semua orang yang hidupnya berhasil dan menjadi orang besar, pernah melakukan kesalahan; (h) manajemen waktu, dalam mengajar guru harus menyelesaikan materi dalam kurikulum yang harus diajarkannya. Guru mempunyai waktu yang terbatas dalam temu muka dengan murid ketika mengajarkan materi di kelas; (i) penampilan yang menarik, guru itu sama dengan aktor dan aktris yang harus berakting dimuka para audiensnya-yaitu murid. Guru harus bernampilan menarik, dengan wajah yang perilaku professional; (j) bersikap adil dalam mengajar, guru harus membagi perhatian kepada semua muridmuridnya secara adil. Guru memberikan kesempatan bertanya tanpa membedakan siapa muridnya, dan menjawab pertanyaan dengan cara yang sama. Dalam memberi nilai dia juga tidak bias dan sesuai dengan kinerja anak didiknya.

Kepemimpinan guru yang sukses, diadaptasi dari konsep Ordweay Tead Kartono (2010) yang dikutip Priansa (2014:167-169), menguraikan metode kepemimpinan guru yang dapat memengaruhi di [sekolah], yaitu:

\section{Memberi perintah}

Jika guru memberi perintah, maka perintah tersebut hendaknya disampaikan dengan santun namun tegas. Selain itu, pemberintan perintah juga tidak boleh bersifat sombong - seolah guru bertindak sebagai seorang 'bos besar' di sekolah.

2. Celaan dan pujian

Celaan harus diberikan secara objektif dan tidak bersifat subjektif, juga tidak disertai emosi-emosi yang negatif (benci, dendam, curiga, dan lain sebagianya).

3. Memupuk tingkah laku pribadi yang benar Guru harus bersifat objektif dan jujur. Ia juga harus menjauhkan diri dari rasa pilih kasih atau favoritisme tertentu.

4. Peka terhadap saran dan nasehat Guru harus memiliki sifat yang luwes, terbuka, dan peka terhadap saran-saran eksternal yang sifatnya positif.

5. Memperkuat rasa kesatuan kelompok

Perasaan kebersamaan sangat penting dalam sebuah komunitas-tidak individualis.

6. Memiliki tim kerja

Tim kerja merupakan kunci untuk menuju operasi yang sukses. Diawali mulai unit terkecil hingga yang terbesar harus menjadi satu kesatuan hingga memiliki satu visi dan misi yang pada akhirnya akan mempermudah pencapaian tujuan yang diinginkan oleh sekolah.

7. Mengembangkan rasa tanggung jawab

Penyampaian kekuasaan yang disertai dengan pertanggungjawaban akan mengembangkan rasa kepercayaan serta rasa hormat di antara guru, staf administratif, serta pegawai lainnya.

8. Membuat keputusan tepat pada waktunya Guru perlu memiliki kemampuan cepat dan tepat dalam meramal berbagai situasi yang dihadapi sehingga dapat menghasilkan keputusan yang bijaksana.

Dengan demikian, kepemimpinan guru harus adil, energik, optimis, memberi perintah, memiliki rasa humor, manajemen waktu yang baik, penampilan yang menarik, mencintai anak didik, objektif dan tegas dalam mengambil keputusan.

\section{Kepemimpinan Guru PAK}

Konsep kepemimpinan guru sudah mulai dikenal luas dalam lingkungan akademik. Lowery-Moore, Latimer dan Villate (2016) berargumentasi bahwa kepemimpinan guru diketahui sebagai sebuah bidang penting pada 
tahun 1980-an dan kemudian berbagai artikel dan buku telah ditulis tentang bidang tersebut.

Guru sebagai pemimpin dalam kegiatan belajar mengajar akan memiliki pola perilaku yang khas dalam memengaruhi para murid yang disebut gaya kepemimpinan guru. Menurut Rohani (2004:130) model atau tipe kepemimpinan guru ada tiga, yaitu:

a. Otoriter

Otoriter (authoritarian), secara harfiah, otoriter berarti berkuasa sendiri atau sewenang-wenang. Dengan menerapkan gaya kepemimpinan yang otoriter, peserta didik hanya akan aktif kalau ada guru dan kalau peserta didik tidak diawasi, maka semua ativitas menjadi menurun.

b. Laizzes Faire

Laizzes faire merupakan model kepemimpinan yang biasanya tidak produktif walaupun ada pemimpin, karena kalau guru ada peserta didik lebih banyak melakukan kegiatan yang sifatnya ingin diperhatikan.

c. Demokratis

Tipe (gaya) kepemimpinan guru yang demokratis lebih memungkinkan terbinanya sikap persahabatan guru dan peserta didik dengan dasar saling memahami dan saling mempercayai.

Berdasarkan uraian dari ketiga model kepemimpinan di atas, model kepemimpinan Guru PAK yang sangat baik adalah demokratis karena memiliki karakteristik yang cocok dalam konteks sekolah, yaitu mau bekerja sama dengan rekan-rekan sejawat dan para siswa. Hal ini dapat terwujud dari keberhasilan guru dengan memberikan peluang pengembangan akademis bagi siswa. Keberhasilan kepemimpinan guru PAK ditunjukkan dengan sikap hati yang tidak berorientasi pada barangbarang berharga, uang, gaji, insentif, fasilitas, dan berbagai kemudahan kemudahan. Guru yang memimpin tanpa hati dan hanya berdasarkan kekuasaan dan posisinya, hanya menjadikan siswa sebagai penakut dan tidak kreatif. Namun, guru sebagai pemimpin yang telah diperbaharui hatinya haruslah bekerja keras melakukan pekerjaan yang baik tanpa bersungut-sungut.

Firman Tuhan pada Efesus 4:32 dapat dijadikan pedoman untuk pemimpin Kristen atau Guru PAK “Tetapi hendaklah kamu ramah seorang terhadap orang lain, penuh kasih mesra, dan saling mengampuni sebagaimana Allah di dalam Kristus telah mengampuni kamu". Seorang pemimpin yang ramah tidak berarti melupakan disiplin dan aturan. Ramah diartikan sebagai suatu sikap hati, bahwa yang dipimpin itu pada dasarnya manusia yang mempunyai harkat dan martabat yang harus dihormati, disiplin dan aturan ditegakkan dan kasih yang terdalam, menegakkan disiplin bila dilakukan dengan tidak ramah akan menciptakan pemimpin yang otoriter dan tidak mau mendengarkan keluhan-keluhan yang dipimpinnya.

Hal serupa, seperti yang dijelaskan di atas, sebenarnya, harus dilakukan guru Pendidikan Agama Kristen (PAK) di sekolah. Sebagai pemimpin bagi siswa, guru PAK seyogianya memberikan pengajaran kepada siswa tentang kebenaran Firman Tuhan yang bersumber dari Alkitab. Di lingkungan gereja, peran guru PAK adalah sebagai pengajar dan fasilitator yang membawa umat Tuhan tetap berjalan dalam terang kasih-Nya. Sedangkan guru sekolah minggu memiliki tanggung jawab untuk membawa anak-anak kecil mengenal kasih Tuhan. Dengan kata lain, guru PAK atau guru sekolah minggu mengemban tanggung jawab memimpin umat datang kepada Tuhan sebagaimana yang dilakukan oleh pemimpin dalam Alkitab.

Senduk dalam Willy (2009: 88) menyampaikan secara terperinci tujuh kondisi hati yang harus dimiliki seorang pemimpin Kristen [termasuk guru PAK], yaitu:

1. Rendah hati. Sifat yang harus dimiliki, jangan sombong, tinggi hati, karena keberhasilan dan merasa lebih orang lain. Semua keberhasilan yang dimiliki adalah anugerah Tuhan; 
2. Hancur hati. Turut berduka dengan orang yang berduka, turut merasakan kesusahan orang yang susah. Mendoakan nasib buruk sesama dengan hati yang hancur dan berusaha membantu mereka dengan perbuatan nyata;

3. Hati yang lapar dan haus kebenaran. Maksudnya mau memerhatikan, mendengarkan, dan membaca firman Tuhan dengan perbuatan nyata;

4. Hati yang lembut. Jangan kasar dan keras hati, tetapi bersikap sabar dan ramah satu terhadap yang lain, sifat lemah lembut dan penuh kasih;

5. Hati berbelas kasihan. Selalu mengingat orang lain yang selalu membutuhkan pertolongan. jangan hanya mengingat diri sendiri dari kepentingan pribadi serta melupakan orang lain;

6. Hati yang suci. Pandanglah Tuhan terus dan berjalanlah dengan iman serta lakukanlah kehendak Tuhan;

7. Hati yang damai. Tenang, tentram, dan rukun seorang dengan yang lain, berdirilah selalu dalam kebenaran Kristus.

Memimpin dengan hati yang bijaksana merupakan syarat mutlak untuk menjadi pemimpin yang melayani. Pelayanan dalam suatu kepemimpinan adalah bagian yang tidak terpisahkan dari kepemimpinan dengan hati atau kepemimpinan Kristen. Jadi, yang menjadi motivasi paling dasar dari pemimpin yang mau memimpin dengan hati adalah motivasi untuk melayani. Oswald dalam Willy (2009: 88) mengatakan bahwa "Kebesaran Sejati" pada kepemimpinan yang sebenarnya hanya dapat dimanifestasikan bukan dengan menjabarkan manusia menjadi tenaga-tenaga yang melayani, melainkan dengan memberikan diri kepada bawahan dalam pelayanan tanpa pamrih".

Sebagai pemimpin, memang harus mengerjakan berbagai macam program, hal ini tidak dapat dielakkan. Tugas Pemimpin Kristen yang melayani adalah melayani kepentingan orang lain bukan dengan kepentingan diri sendiri (Filipi 2:4). Pemimpin yang melayani harus juga sebagai pemimpin yang mau bekerja sama dan saling melayani. Banyak pemimpin, tidak saja pemimpin sekuler tetapi juga kepemimpinan kegamaan termasuk pemimpin Kristen, tidak menerapkan kepemimpinan yang kolektif, yang artinya ada yang tidak mau mendengarkan dan menerima saran atau masukan yang positif untuk kemajuan organisasi yang dipimpinnya. Willy (2009: 92) menyampaikan ada tiga cara memimpin dengan hati yang melayani yaitu: (a) pandanglah pekerjaan sebagai sesuatu yang memuliakan Tuhan; (b) anggaplah pekerjaan itu sebuah kesempatan melayani sama seperti melayani Tuhan; dan (c) pandanglah kehidupan ini sebagai sebuah kesempatan membantu orang lain menjadi lebih baik. Dengan demikian, hidup akan lebih bermakna bukan hanya untuk diri sendiri tetapi juga kepada orang yang dilayani.

\section{SIMPULAN}

Kepemimpinan guru agama Kristen merupakan salah satu faktor penentu keberhasilan belajar siswa. Guru agama Kristen dapat melaksanakan tugas lebih baik lagi apabila memiliki karakteristik kepemimpinan seperti melayani dengan hati, adil dengan kebenaran firman Tuhan, semangat yang energik dalam Tuhan, optimis memberi perintah, manajemen waktu yang baik, mengasihi anak didik, objektif dan tegas dalam mengambil keputusan. Dengan adanya karakteristik yang demikian, kepemimpinan guru agama Kristen besar kemungkinannya akan berhasil. Oleh karena itu, kepemimpinan guru agama Kristen dalam kegiatan belajar mengajar di sekolah sebaiknya dipahami lebih baik lagi supaya dapat diimplementasikan, sehingga selanjutnya dapat menumbuhkan semangat belajar dan meningkatkan hasil belajar siswa.

\section{DAFTAR PUSTAKA}

(2010). Himpunan Peraturan Perundang-undangan Sisdiknas: Sistem 
Pendidikan Nasional. Bandung: Fokus Media.

. (2012). Alkitab. Jakarta: Lembaga Alkitab Indonesia.

Berg, J. H., \& Zoellick, B. (2018). Teacher leadership: toward a new conceptual framework. Journal of Professional Capital and Community, 4(1), 2-14.

Harris, A. (2015). Teacher leadership. International Encyclopedia of the Social \& Behavioral Sciences, 2nd edition, 24, 60-63.

Hasanah, D. S., \& Fattah, N. (2010). Pengaruh pendidikan Latihan (Diklat) Kepemimpinan Guru dan Iklim Kerja terhadap Kinerja Guru Sekolah Dasar se Kecamatan Babakan Cikao Kabupaten Purwakarta. Jurnal Penelitian Pendidikan, 11(2), 85-96.

Hine, G. S. (2014). Student Leadership Development: A Functional Framework. Journal of Catholic Education, 18 (1), 79-110. http://dx.doi.org/10.15365/joce.180105 2014

Hook, D. P. (2006). The impact of teacher leadership on school effectiveness in selected exemplary secondary schools (Doctoral dissertation, Texas A\&M University). Diakses dari https://oaktrust.library.tamu.edu/handle /1969.1/3740

Lowery-Moore, H., Latimer, R. M., \& Villate, V. M. (2016). The essence of teacher leadership: A phenomenological inquiry of professional growth. International Journal of Teacher Leadership, 7(1), 1-16.
Lumban Gaol, N. T. (2017). Teori dan implementasi gaya kepemimpinan kepala sekolah. Kelola: Jurnal Manajemen Pendidikan, 4(2), 213-219.

Priansa, D. J. (2014) Kinerja Profesionalisme Guru. Bandung: Alfa Beta.

Rohani, A. (2004). Pengelolaan pengajaran. Jakarta: PT Rineka Cipta.

Sari, I. N. (2017). Kepemimpinan MoralSpiritual Guru dalam Pembentukan Karakter Peserta Didik.(Studi Multikasus di Sekolah Dasar Plus Al Kautsar, Sekolah Dasar Negeri Kauman I, dan Sekolah Dasar Katolik Santa Maria II di kota Malang). (Disertasi Program Pascasarjana UM). Diakses dari http://karyailmiah.um.ac.id/index.php/disertasi/arti cle/view/63200

Soetopo, H. \& Soemanto. W. (2008). Kepemimpinan dan Supervisi Pendidikan. Jakarta: PT Bina Aksara.

Tomatala, Y. (2002). Kepemimpinan Kristen. Jakarta: YT Leadership Foundation.

Warren, L. L. (2018). Behaviors of teacher leaders in the classroom. Psychology and Behavioral Sciences. 7(6), 104-108.

Willy, J., S. (2009). Lead By Heart Kepemimpinan Andal yang Menggunakan hati. Yogyakarta: Andi.

Winardi. 2000. Kepemimpinan dalam manajemen. Jakarta: PT Rineka Cipta

Wirawan, M. S. L. (2013). Kepemimpinan. Jakarta: PT Rajagrafindo Persada

Wolterstorff, N. P. (2014). Mendidik untuk Kehidupan: Refleksi mengenai pengajaran dan pembelajaran Kristen (Terjemahan). Surabaya: Momentum. 